Human \& Animal Health

Vol.59: e16150529, January-December 2016 http://dx.doi.org/10.1590/1678-4324-2016150529

BRAZILIAN ARCHIVES OF BIOLOGY AND TECHNOLOGY

ISSN 1678-4324 Online Edition

AN INTERNATIONAL JOURNAL

\title{
Cytotoxic Effect on Cancerous Cell Lines by Biologically Synthesized Silver Nanoparticles Kulandaivelu, Balaji ${ }^{1}$; Gothandam, $\mathbf{K}^{\mathbf{1}}{ }^{\mathbf{*}}$. \\ ${ }^{1}$ VTI University, School of Bio Sciences and Technology Vellore, Tamil Nadu, India
}

\begin{abstract}
The biosynthesis of nanoparticles has been proposed as an environmental friendly and cost effective alternative to chemical and physical methods. Silver nanoparticles are biologically synthesized and characterized were used in the study. The invitro cytotoxic effect of biologically synthesized silver nanoparticles against MCF-7 cancer cell lines were assessed. The cytotoxic effects of the silver nanoparticles could significantly inhibited MCF-7 cancer cell lines proliferation in a time and concentration-dependent manner by MTT assay. Acridine orange, ethidium bromide (AO/EB) dual staining, caspase-3 and DNA fragmentation assays were carried out using various concentrations of silver nanoparticles ranging from 1 to $100 \mu \mathrm{g} / \mathrm{mL}$. At $100 \mu \mathrm{g} / \mathrm{mL}$ concentration, the silver nanoparticles exhibited significant cytotoxic effects and the apoptotic features were confirmed through caspase-3 activation and DNA fragmentation assays. Western blot analysis has revealed that nanoparticle was able to induce cytochrome c release from the mitochondria, which was initiated by the inhibition of Bcl-2 and activation of Bax. Thus, the results of the present study indicate that biologically synthesized silver nanoparticles might be used to treat breast cancer. The present studies suggest that these nanoparticles could be a new potential adjuvant chemotherapeutic and chemo preventive agent against cytotoxic cells. However, it necessitates clinical studies to ascertain their potential as anticancer agents.
\end{abstract}

Key words: Silver nanoparticle; nanotechnology; nanobiotechnology; nanoparticle; cytotoxicity

\footnotetext{
*Author for correspondence: gothandam@gmail.com
} 
Gothandam, K M et al.

\section{INTRODUCTION}

Nanotechnology is an escalating field of modern research with desired applications in electronic and medicine and has been expanding rapidly in recent years, impacting on diverse areas such as the economy and the environment (Badri Narayanan et al. 2010). In this context, the number of commercial products comprising nanomaterials is increasing. Among the commercially available nano-sized materials, silver nanoparticles are by far the most used nanocompounds (Ahmed et al. 2008) currently, sustainability initiatives that use green chemistry to improve and/or protect our global environment are focal issues in many fields of research. The biogenic synthesis of metal NPs reduces these hazards through the elimination / minimization of generated waste and the implementation of sustainable processes. Biological methods of NPs synthesis using microorganisms (Klaus et al. 1999; Konishi et al. 2007), enzymes (Willner et al. 2006) have been studied as possible ecofriendly alternatives to chemical and physical methods. Among all the noble metals, silver has attracted major attention due to its disinfecting nature and tremendous medicinal value to culinary items as well as showing enormous effectiveness as an anticancer agent. Moreover, several salts of silver and their derivatives are commercially manufactured as antimicrobial agents (Krutyakov et al. 2008).Breast cancer is the second leading cause of cancer death among women in the U.S. An estimated 39,620 breast cancer deaths and 232,340 new cases are expected among women in 2013 (AMS, 2014). The existing cytotoxic agents used for the breast cancer treatment are found to be expensive and inefficient because they induce severe side effects due to their toxicity in noncancerous tissues (Kim et al. 2007; Yeruva et al. 2008) Earlier studies show that the cytotoxicity of synthesized Ag NPs is related to the involvement of the level of cellular reactive oxygen species (ROS) and mitochondrial membrane disruption (Asha Rani et al. 2009; Sanpui et al. 2011). The present study also tried to validate the possible invitro anti-proliferative effects of green synthesized Ag NPs against the breast cancer cell lines.

\section{MATERIALS AND METHODS}

\section{Biological synthesis of AgNPs}

AgNPs using fungus Trichoderma viride was procured, synthesized and characterised. In the present investigation the use of the fungus Trichoderma viride for the extracellular biosynthesis of AgNPs from silver nitrate solution is reported (Fayaz et al. 2009). It was observed that the aqueous silver $(\mathrm{Ag}+)$ ions, when exposed to a filtrate of $T$. viride, were reduced in solution, thereby leading to formation of extremely stable AgNPs. These AgNPs were characterized by means of several techniques. The nanoparticles show maximum absorbance at $420 \mathrm{~nm}$ on ultraviolet-visible spectra. The presence of proteins was identified by Fourier transforminfrared spectroscopy. The reduction of $\mathrm{Ag}+$ ions to elemental silver was characterized by $\mathrm{x}$-ray photoelectron spectrophotometry. Electrokinetic measurements (zeta potential) of AgNPs as a function of $\mathrm{pH}$ in $1 \times 10-3 \mathrm{~mol}$ $\mathrm{dm}-3$ aqueous solution were evaluated. The transmission electron micrograph revealed the formation of poly-dispersed nanoparticles of 5-40 nm, and the presence of elemental silver was confirmed by energy-dispersed spectroscopy analysis (Fayaz et al. 2009).

\section{Cell lines and culture conditions}

All MCF-7 cell lines were grown in RPMI1640 supplemented with $10 \%$ heat inactivated fetal bovine serum (FBS), $100 \mathrm{IU} / \mathrm{ml}$ penicillin, $100 \mathrm{mg} / \mathrm{ml}$ streptomycin and 2 mm-glutamine. Cultures were maintained in a humidified atmosphere with $5 \% \mathrm{CO}_{2}$ at $37^{\circ} \mathrm{C}$. The cells were sub-cultured twice each week, seeding at a density of about $2 \times 10^{3}$ cells $/ \mathrm{ml}$. Before the analysis of the AgNPs, cells were washed with PBS and fresh medium was added. For final analysis, exponentially growing cells were collected and resuspended in fresh culture medium with $10 \%$ FBS. 


\section{MTT assay}

The silver nanoparticles (BK1) were evaluated for cytotoxic activity against MCF7 breast cancer cell line. The cells were plated separately in 96 well plates at a concentration of $1 \times 10^{5}$ cells/well. After $24 \mathrm{~h}$, cells were washed twice with $100 \mu \mathrm{L}$ of serum-free medium and starved for an hour at $37^{\circ} \mathrm{C}$. After starvation, cells were treated with the test material for $24 \mathrm{~h}$. At the end of the treatment period the medium was aspirated and serum free medium containing MTT $(0.5 \mathrm{mg} / \mathrm{mL})$ was added and incubated for $4 \mathrm{~h}$ at $37^{\circ} \mathrm{C}$ in a $\mathrm{CO}_{2}$ incubator. The MTT containing medium was then discarded and the cells were washed with PBS $(200 \mu \mathrm{L})$. The crystals were then dissolved by adding $100 \mu \mathrm{L}$ of DMSO and this was mixed properly by pipetting up and down. Spectrophotometrical absorbance of the purple blue formazan dye was measured in a microplate reader at $570 \mathrm{~nm}$ (Biorad 680). The experiment was carried out in triplicates and the average of the viable cells was calculated. A graph was plotted between the percentage cell viability and dilution.

\section{Caspase-3 activation in fold by Enzyme linked immunosorbent assay (ELISA)}

Caspase-3 is an intracellular cysteine protease that exists as a proenzyme, becoming activated during the cascade of events associated with apoptosis. Caspases activities were determined by chromogenic assays using caspase - 3 activation kits according to the manufacturer's protocol (Calbiochem, Merck). After treating with test compound, the cells were lysed using Lysis buffer $(50 \mathrm{mM}$ HEPES, $100 \mathrm{mM} \mathrm{NaCl}, 0.1 \%$ CHAPS, $1 \mathrm{mM}$ DTT, $100 \mathrm{mM}$ EDTA). Lysates were centrifuged at 10,000 rpm for $1 \mathrm{~min}$. The supernatants (cytosolic extract) were collected and protein concentration was determined by the Lowry's method (Lowry 1951) using BSA as a standard. $100 \mu \mathrm{g}$ protein (cellular extracts) was diluted in $50 \mu \mathrm{L}$ cell lysis buffer for each assay. Cellular extracts were then incubated in 96 well microtiter plates with 5 $\mu \mathrm{L}$ of the $4 \mathrm{mM} \mathrm{p}$-nitroanilide (pNA) substrates, DEVD--pNA (caspase-3 activity) for $2 \mathrm{~h}$ at $37^{\circ} \mathrm{C}$. Caspase activity was measured by cleavage of the above substrates to free pNA. Free pNA (cleaved substrates) was measured at $405 \mathrm{~nm}$ in a microtiter plate reader. Relative caspase-3 activity was calculated as a ratio of the absorbance of treated cells to untreated cells.

\section{Acridine orange/ethidium bromide dual staining}

In this study, we used acridine orange/ethidium bromide (AO/EB) double staining assay (Popovic et al. 2006). Acridine orange is taken up by both viable and nonviable cells and emits green fluorescence if interrelated into double stranded nucleic acid (DNA) or red fluorescence if bound to single stranded nucleic acid (RNA). Ethidium bromide is taken up only by nonviable cells and emits red fluorescence by intercalation into DNA. We distinguished four types of cells according to the fluorescence emission and the morphological aspect of chromatin condensation in the stained nuclei. Viable cells have uniform bright green nuclei with organized structure. Apoptotic cells have orange to red nuclei with condensed or fragmented chromatin was examined by a fluorescence microscope at $400 \mathrm{X}$ magnification. Necrotic cells have a uniformly orange to red nuclei with condensed structure.

\section{DNA fragmentation assay}

In 24 flat-wells plate, incubated $2 \times 10^{5}$ MCF 7 in DMEM medium for $24 \mathrm{~h}$ (triplicate wells of $10^{5}$ per well) with different concentration of BK1. Cells were harvested and re-suspend with $0.5 \mathrm{~mL}$ PBS and $55 \mu \mathrm{L}$ of lysis buffer (40 mL of $0.5 \mathrm{M}$ EDTA $5 \mathrm{~mL}$ of $1 \mathrm{M}$ Tris-Cl buffer $\mathrm{pH} 8.05 \mathrm{~mL}$ of $100 \%$ Triton X-100 50 $\mathrm{mL}$ of $\mathrm{H} 2 \mathrm{O}$ ) incubated for $20 \mathrm{~min}$ on ice. Cell suspension was centrifuged at 12,000 $\mathrm{g}$ for 30 min at $4^{\circ} \mathrm{C}$. The supernatant was extracted with 1:1 mixture of phenol:chloroform and precipitated in two volume of cold ethanol and one-tenth volume of sodium acetate. Pellet was re-suspended in $30 \mu \mathrm{L}$ of deionized water-RNase solution. The DNA were resolved in $1.2 \%$ agarose gel.

\section{Western blotting}

A modified version of (Cavalieri et al. 2004) was employed for estimation of Caspases, 
Bax and Bcl-2. Exponentially growing cells (1 x $10^{6}$ cells $/ \mathrm{mL}$ ) were plated in six well plates and after the addition of nanoparticles at 1000 $\mu \mathrm{g}$ were incubated for different time points (0-24). Cells incubated for different periods of time were harvested by centrifugation at $500 \mathrm{~g}$ for $5 \mathrm{~min}$, washed twice with PBS and homogenized in $200 \mathrm{ll}$ of lysis buffer containing $10 \mathrm{mM} \mathrm{NaCl}, 1.5 \mathrm{mM} \mathrm{MgCl} 2,10$ $\mathrm{mM}$ Tris- $\mathrm{HCl}, 1 \mathrm{mM}$ sodium orthovanadate, $0.3 \%$ NP40 and protease inhibitor cocktail (EDTA free). The lysates thus obtained were centrifuged at $12,000 \mathrm{~g}$ for $30 \mathrm{~min}$ at $4^{\circ} \mathrm{C}$. Fifty micrograms of the total protein, as determined by Bradford's assay, was resolved into $10 \%$ SDS-PAGE and then transferred to nitrocellulose membrane using a semi dry electroblotter for $2 \mathrm{~h}$ at RT. The membrane was blocked over night in 5\% BSA. In all cases, antibodies raised against active forms of p53, Bcl-2, Bax and b-actin as internal control (Calbiochem, Merck, Germany) were incubated for $2 \mathrm{~h}$ with gentle agitation. After washing three times with Tris buffered saline (TBS; $50 \mathrm{mM}$ Tris/HCl, $\mathrm{pH} 7.5$, and $0.15 \mathrm{M}$ $\mathrm{NaCl}$ ) containing $0.1 \%$ Triton $\mathrm{X}-100$, the membrane was incubated with alkaline phosphatase-conjugated secondary antibodies for $2 \mathrm{~h}$ with agitation. The probed immunoblots were visualized with the NBT/BCIP chromogenic substrate and

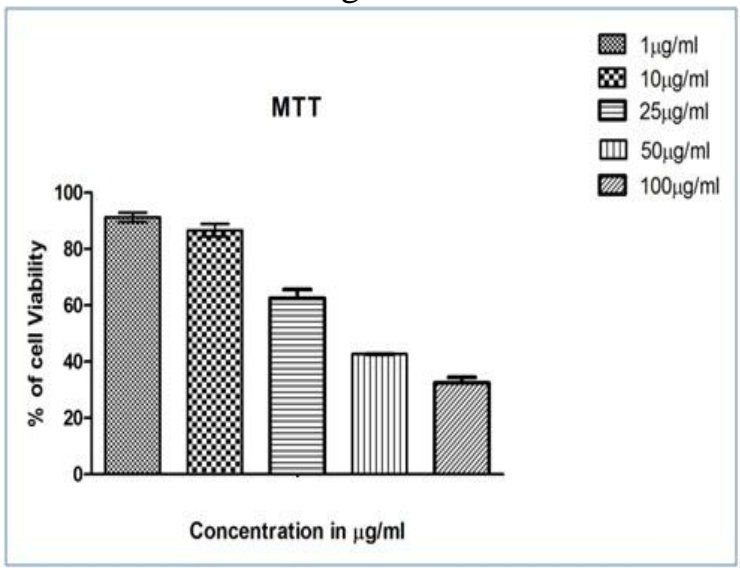

A documented. The optical density of the immunoblots was quantified by densitometric scanning and data were analyzed by Biorad Quantity One software.

\section{RESULTS}

\section{MTT assay}

The anticancer activity of the synthesized silver nanoparticles were evaluated invitro against MCF-7 breast cancer cell lines after $24 \mathrm{~h}$ exposure and their IC50 values were determined from a graph of cell viability measured over a range of concentrations between 1 and $100 \mu \mathrm{g} / \mathrm{mL}$. The IC50 was determined at a broad range of concentrations specifically $1,10,25,50 \& 100 \mu \mathrm{g} / \mathrm{mL}$ against the cell lines. For this data, a line graph was plotted between concentrations (Xaxis) versus $\%$ inhibition (Y-axis) and then an intersection drawn at $50 \%$ inhibition on $\mathrm{Y}$ axis and then correlated to the concentration value on $\mathrm{X}$-axis. From the data it is revealed that silver nanoparticle exhibited different range of significant cytotoxic activities varying from $94.91 \mu \mathrm{g} / \mathrm{mL}$ to $34.51 \mu \mathrm{g} / \mathrm{mL}$ due to structural differences. Their bioactivity data is presented in the graphical representation also (Fig. 1).

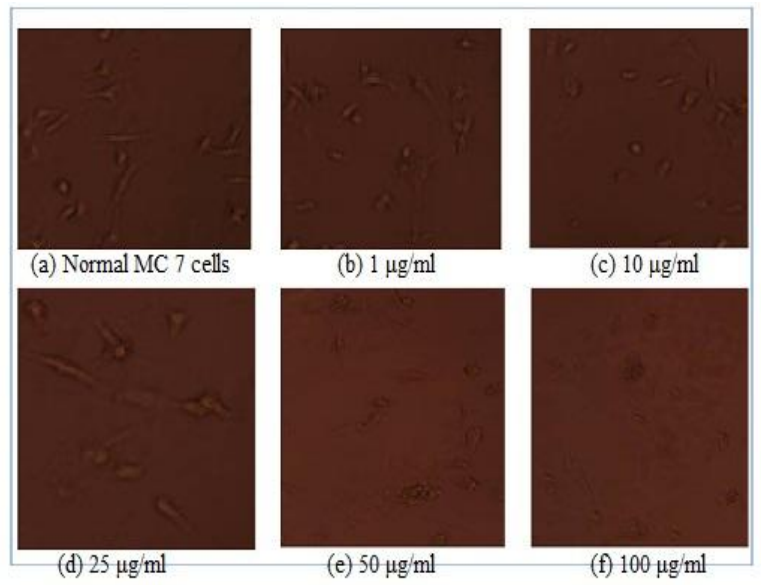

B

Figure 1 - A. Dose dependent cytotoxicity effect of SNp over cell viability. B. Morphological changes of MCF 7cells cell lines treated with SNp .Cells were visualized under a inverted light microscope. Detachment of cells from substratum, cell shrinkage, nuclear condensation and fragmentation were evident in cells treated (a) Normal MCF 7cells(b) Low toxicity $1 \mu \mathrm{g} / \mathrm{mL}$ (c) toxicity $10 \mu \mathrm{g} / \mathrm{mL}$ (d) toxicity $25 \mu \mathrm{g} / \mathrm{ML}$, (e) $50 \mu \mathrm{g} / \mathrm{mL}$, (f) $100 \mu \mathrm{g} / \mathrm{mL}$. 


\section{Caspase-3}

To investigate whether apoptosis is mediated by caspase-3, cell lysates treated with, silver nanoparticles was analysed. Levels of caspase-3 were found to be elevated in the silver nanoparticles treated tumour cells (Fig.
2). The increased levels of caspase-3 activation suggest that silver nanoparticles induced apoptosis in MCF 7 breast cancer cells in a caspase-3-dependent manner.

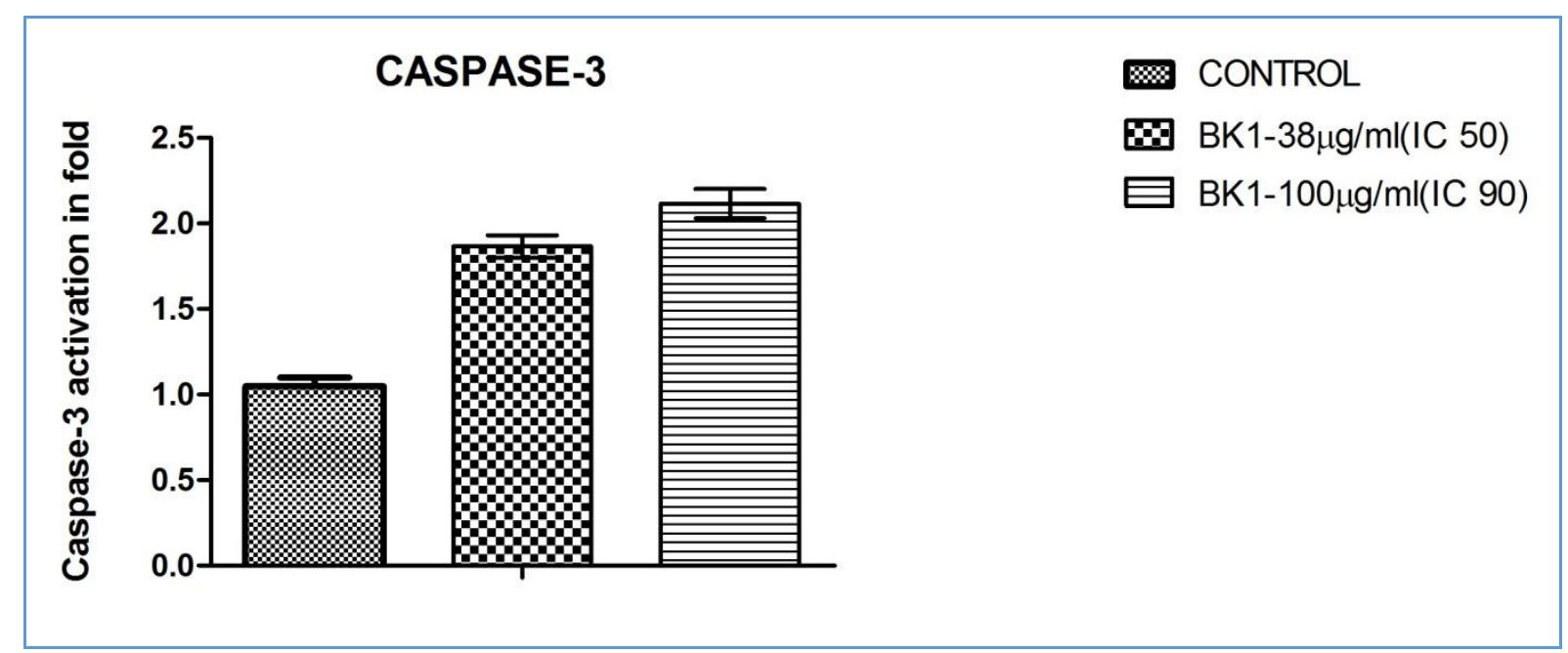

Figure 2- Metal nanoparticles induced apoptosis in MCF 7 breast cancer cells via caspase-3 (Caspase assay).

Morphological evidence of apoptosis by dual staining

Apoptotic morphological changes caused by silver nanoparticles were studied using acridine orange/ethidium bromide differential staining method. The stained cells were characterized to viable (light green), early apoptotic (bright green fluorescence and condensed chromatin), late apoptotic (orange fluorescence) and nonviable cells (red coloured fluorescence) (Fig. 3 a-c). Silver nanoparticles treated cells showed condensed nuclei, membrane blebbing and apoptotic bodies. In contrast, the control cells showed intact nuclear architecture.

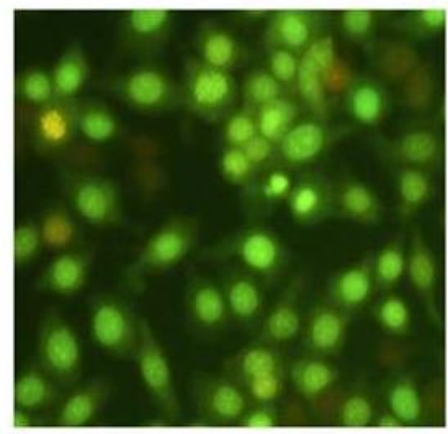

A

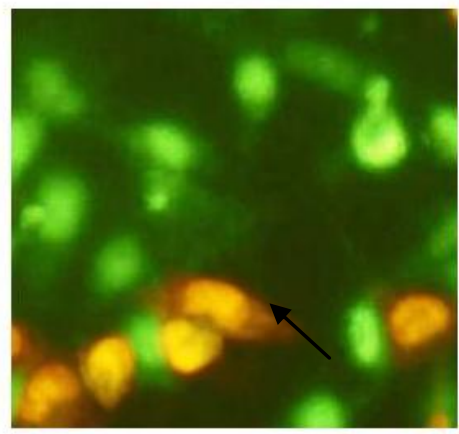

B

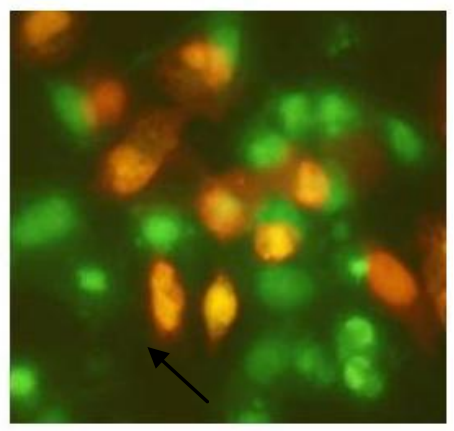

C

Figure 3- Morphological evidence of apoptosis by AO/EB dual staining (A) $10 \mu \mathrm{g} / \mathrm{mL}$ (B) $20 \mu \mathrm{g} / \mathrm{mL}$ (C) 40 $\mu \mathrm{g} / \mathrm{Ml}$

\section{DNA fragmentation assay}

The evaluation of apoptosis was further carried out by determining the DNA fragmentation patterns, MCF-7 cells treated with the extracts showed characteristics of
DNA laddering that had apoptotic cells higher when treated even at low concentration $(20 \mu \mathrm{g} / \mathrm{mL})$. The difference in effect towards cancer cells could be targeting a particular molecular event exclusively in tumor cells 
Gothandam, K M et al.

and showed that the silver nanoparticles treated exhibited extensive double strand breaks, thereby yielding a ladder appearance shown in (Lane 2), while the DNA of control MCF 7cells supplemented with $10 \%$ serum exhibited minimum breakage (Lane 1) (Fig. 4).

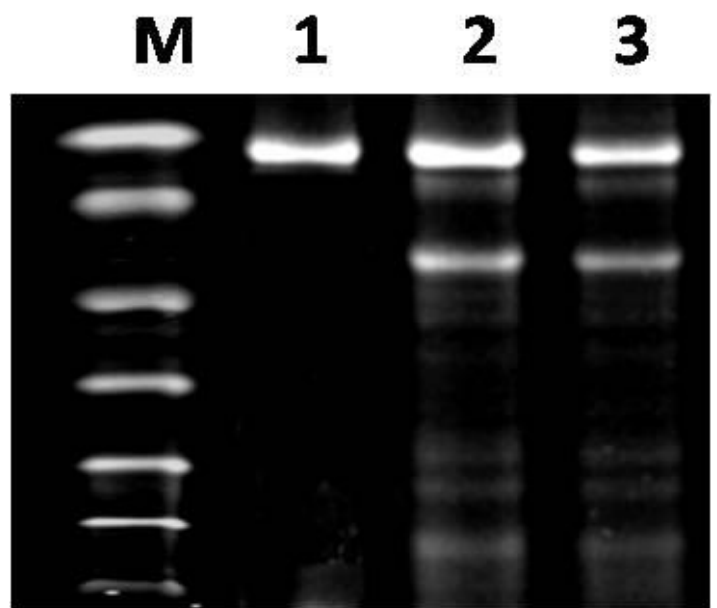

Figure 4 - DNA fragmentation assay. DNA fragmentation assay lane 1 (control), lane 2 (IC50$40 \mu \mathrm{g} / \mathrm{mL}$ treated), lane 3 (IC90- $130 \mu \mathrm{g} / \mathrm{mL}$ treated)

\section{Western blotting}

The apoptosis was found under the regulation of Bcl-2 family proteins indicating caspases were activated during the process and suggesting a caspase-dependent pathway. Evidence showing the release of cytochrome $\mathrm{c}$ from the mitochondrial intermembrane space was confirmed by caspase assay. The expression fold was compared with control compound markedly increased the activities of p53 and Bax but downregulation in Bcl-2 at a concentration of $50 \mu \mathrm{g}$ at $24 \mathrm{~h}$. The results strongly suggest that nanoparticle induces apoptosis via caspase-dependent manner (Fig. 5).
P 53

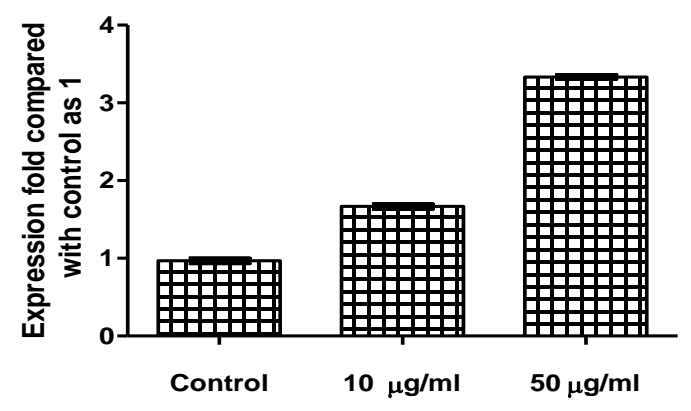

BCL-2

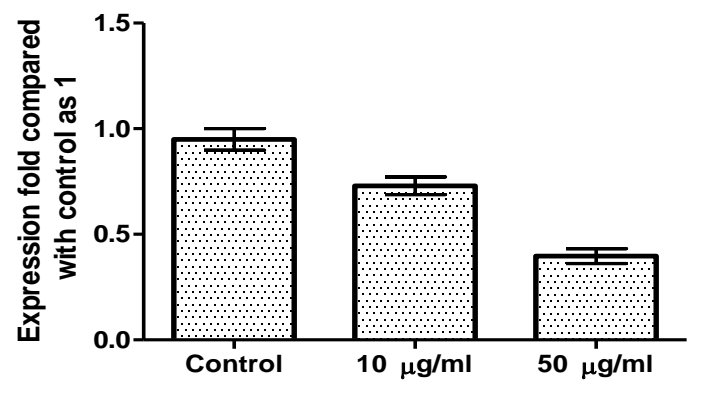

BAX

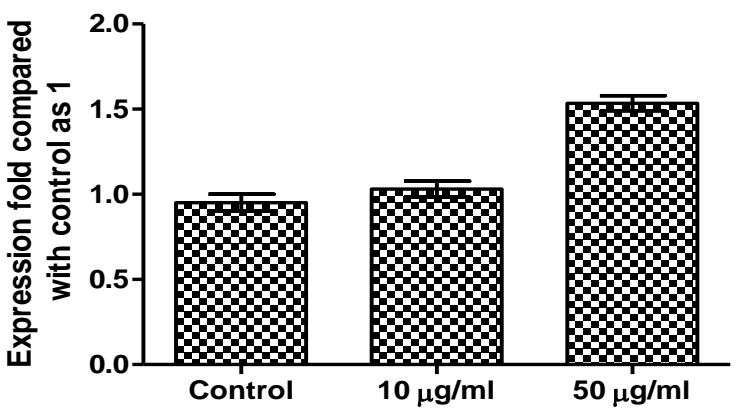

Figure 5 - Western blot analysis of nanoparticles induced apoptosis via caspase-dependent pathway (p53, Bcl-2 and Bax).

\section{DISCUSSION}

Silver nanoparticles are considered cytotoxic and cell exposure is considered to be an early step in apoptosis. The mechanism(s) linked to silver nanoparticle cytotoxicity is not completely understood. Chen and Schluesener (2008) agreed that silver nanoparticle interaction with the thiol groups of the mitochondrial inner membrane occurs. They indicated that this leads to the depletion of the antioxidant defence mechanism which, in turn, led to the formation of ROS. The ROS accumulation leads to an inflammatory 
response. The cells' inflammatory response initiated the destruction of mitochondria, which provoked the release of apoptogenic factors that induce cell death.

Supporting these studies is a study by Hussain et al. (2005) who looked at toxic response of silver nanoparticles (15 and 100 $\mathrm{nm}$ ) in BRL 3A rat liver cells. They found that silver nanoparticles induce a toxic response in this cell type. Also, they determined that mitochondrial function diminished considerably in cells exposed to silver nanoparticles at $5-50 \mu \mathrm{g} / \mathrm{mL}$ (Hussain et al. 2005). It was also determined that there was significant LDH leakage across the membrane in cells exposed to silver nanoparticles from 10-50 $\mu \mathrm{g} / \mathrm{mL}$ (Hussain et al. 2005). It was observed that along with the reduced mitochondrial membrane potential, there was an increase in ROS levels suggesting that the cytotoxicity of nanosilver was probably mediated through oxidative stress (Hussain et al. 2005). Also, the team observed that there was an increase in ROS generation with an increase in nanoparticle concentration. The study showed that after an exposure of $24 \mathrm{~h}$, the cells showed a concentration dependent LDH leakage with significant cytotoxicity at $10-50 \mu \mathrm{g} / \mathrm{mL}$ (Hussain et al. 2005). This team not only studied silver nanoparticles, but also other nanomaterials $(\mathrm{MoO} 3, \mathrm{Al}, \mathrm{Fe} 3 \mathrm{O} 4$, and $\mathrm{TiO} 2)$. They determined through the use of MTT and LDH assays that the silver nanoparticles were more toxic than the other nanomaterials noted above. Apoptosis is a tightly regulated process, which involves changes of a distinct gene expression. Among the numerous factors known to modulate cancer-related apoptosis, several pro- and antiapoptotic genes can be used as markers of apoptosis, such as p53, Bcl-2 and Bax. The tumor suppressor gene p53 acts as both an inducer (Clarke et al. 1993). From this study, it was concluded that biosynthesis of silver nanoparticles possess potential anticancer applications. The characterization analysis proved that the particle so produced in nanodimensions would be equally effective as that of anticancer drugs and other drugs in pharmaceutical applications. The use of silver nanoparticles in drug delivery systems might be the future thrust in the field of medicine. It was concluded that the silver nanoparticles can serve as a potential drug with various clinical and pharmacological properties, thereby demonstrating enhanced characteristic anti cancer activity, anti apoptotic activity, anti oxidant activity, wound healing activity and antimicrobial activity.

\section{CONCLUSION}

Investigations showed that these silver particles are nontoxic within the studied range of concentrations, actively penetrate in cancerous cells. It is necessary to take these data into account when developing on structured preparations for internal administration, based on silver colloids. In addition, on the basis of our data and the data obtained, it may be concluded that silver nanoparticles can serve not only as inert platform-type carriers for medical preparations but also as active reagents able (depending on size and possibly charge) to affect the functions of cell systems that are connected with the endosomal, exosomal and lysosomal system. In conclusions, sliver nanoparticles possess considerable anticancer effect. Use of AgNPs should emerge as one of the novel approaches in cancer therapy and, when the molecular mechanism of targeting is better understood, the applications of AgNPs are likely to expand further, However, more studies are needed to better understand the genotoxicity mechanisms, as well as the correlations between nanoparticles and their impact on the human health and the environment.

\section{REFERENCE}

Ahmed M, Karns M, Goodson M, Rowe J, Hussain SM, Schlager JJ, et al. DNA damage response to different surface chemistry of silver nanoparticles in mammalian cells. Toxicol Appl Pharmacol. 2008; 233: 404-410.

Asha RPV, Low Kah Mun G, Hande MP, Valiyaveettil S. Cytotoxicity and genotoxicity of silver nanoparticles in human cells. ACS Nano. 2009; 24: 279-290. 
Gothandam, K M et al.

Badri NK, Natarajan S. Biological synthesis of metal nanoparticles by microbes. Adv. Colloid Interface Sci. 2010; 156: 1 - 13

Cavalieri E, Mariotto S, Fabrizi C, de Prati AC, Gottardo R, Leone S, et al. Alpha-Bisabolol, a nontoxic natural compound, strongly induces apoptosis in glioma cells. Biochem Biophys Res Commun. 2004; 315: 589-594.

Chen X, Schluesener HJ. Nanosilver: a nanoproduct in medical application. Toxicol Lett. 2008; 176: 1-12.

Clarke AR, Purdie C A, Harrison DJ, Morris RG, Bird CC, Hooper M L, et al. Thymocyte apoptosis induced by p53-dependent and independent pathways. Nature. 1993; 362: 849-852.

Fayaz AM, Balaji K, Girilal M, Yadav R, Kalaichelvan PT, Venketesan R. Biogenic synthesis of silver nanoparticles and their synergistic effect with antibiotics: a study against gram-positive and gram-negative bacteria Nanomedicine: Nanotechnol Biol Med. 2009; 6: 103-109.

Hussain SM, Hess KL, Gearhart JM, Geiss KT, Schlager JJ. In vitro toxicity of nanoparticles in BRL 3A rat liver cells. Toxicol In Vitro. 2005; 19: 975-983.

Kim DW, Hong GH, Lee HH, Choi SH, Chun BG, Won CK, Hwang IK, Hussain HM, Hess SM, Gearhart JM, Geiss KT, Schlager JJ. In vitro toxicity of nanoparticles in BRL 3A rat liver cells. Toxicol In Vitro. 2005; 19: 975983.

Klaus T, Joerger R, Olsson E, Granqvist CG. Silver-based crystalline nanoparticles, microbially fabricated. Proc Natl Acad Sci. USA. 1999; 96: 13611-13614.

Konishi Y, Ohno K, Saitoh N, Nomura T, Nagamine S, Hishida $\mathrm{H}$, et al. Bioreductive deposition of platinum nanoparticles on the bacterium Shewanella algae. J Biotechnol. 2007; 128: 648-653

Krutyakov YA, Kudrynskiy A, Olenin AY, Lisichkin GV. Extracellur biosynthesis and antimicrobial activity of silver nanoparticles. Russ Chem Rev. 2008; 77: 233.

Lowry OH, Rosenbrough NJ, Farr A. Randall RJ. Protein measurement with the Folin phenol reagent. J Biol Chem. 1951; 193: 265-275.

Popovic S, Arsenijevic NN, Baskic D, Ristic P. Analysis of cycloheximide-induced apoptosis in human leukocytes: fluorescence microscopy using annexin $\mathrm{V} /$ propidium iodide versus acridin orange/ethidium bromide. Cell Biol Int. 2006; 30: 924-932.

Sanpui P, Chattopadhyay A, Ghosh SS. Induction of apoptosis in cancer cells at low silver nanoparticle concentrations using chitosan nanocarrier. ACS Appl Mater Interfaces. 2011; 3: 218-228.

Willner I, Baron R, Willner B. Growing metal nanoparticles by enzymes. Adv Mater. 2006; 18: 1109-1120

Yeruva L, Elegbede JA, Carper SW. Methyl jasmonate decreases membrane fluidity and induces apoptosis via tumor necrosis factor receptor 1 in breast cancer cells, Anti-Cancer Drug. 2008; 19: 766-776.

Received: September 03, 2015; Accepted: January 26, 2016. 